\title{
Floristic Composition and Diversity of Freshwater Swamp Forests in the Niger Basin of Nigeria
}

\author{
Nwabueze I. Igu1,2, Robert Marchant ${ }^{1}$ \\ ${ }^{1}$ York Institute for Tropical Ecosystems (KITE), Environment Department, University of York, York, UK \\ ${ }^{2}$ Department of Geography and Meteorology, Nnamdi Azikiwe University, Awka, Nigeria \\ Email: nwabuezeigu@gmail.com
}

How to cite this paper: Igu, N. I., \& Marchant, R. (2018). Floristic Composition and Diversity of Freshwater Swamp Forests in the Niger Basin of Nigeria. Open Journal of Forestry, 8, 567-584.

https://doi.org/10.4236/ojf.2018.84035

Received: September 10, 2018

Accepted: October 28, 2018

Published: October 31, 2018

Copyright $\odot 2018$ by authors and Scientific Research Publishing Inc. This work is licensed under the Creative Commons Attribution International License (CC BY 4.0).

http://creativecommons.org/licenses/by/4.0/ Open Access

\begin{abstract}
Freshwater swamp forests are wetland ecosystems with poorly understood ecology. With increasing degradation across the Niger basin (where it is the most extensive across West Africa), it is deemed important to understand its distribution, patterns and composition. This is aimed at both increasing botanical inventories in the ecosystem and also elucidate vital steps that could guide its effective conservation. This study assessed the floristic composition and diversity across 16 one hectare forest plots and sought to show how varied the sites were in terms of diversity, stem density and basal area. The survey showed that the area had 116 species within 82 genera and 36 families. The number of species found in each of the disturbed sites was generally higher than the intact forest sites, which was not diverse but comprised many trees with higher basal area. While the stem density which ranged from 94 409 stems $\cdot h^{-1}$ is comparable with that of other tropical forests, species richness was low (ranging from 8.65 - 0.52). Diversity ranged from $3.38-0.98$ and was higher in disturbed sites than in intact locations. Species richness was generally low and implies that loss of species in the ecosystem could threaten species' existence and conservation in the ecosystem. Disturbed locations had more species than the intact zones and as such show the importance of targeted conservation not only in the undisturbed locations but also in the disturbed locations with a higher species value and potential for species stability of the ecosystem.
\end{abstract}

\section{Keywords}

Biodiversity, Forest Disturbance, Species Rarity, Stem Density, Tropical Forests

${ }^{\star}$ ORCID ID: https://orcid.org/0000-0003-2635-6948. 


\section{Introduction}

Tropical ecosystems are the biologically richest ecosystem on earth (Pimm \& Raven, 2000; Bradshaw et al., 2009; Gibson et al., 2011) and contain up to two third of the earth's terrestrial biodiversity (Gardner et al., 2009). They are very productive ecosystem that provides significant benefits, a wide range of ecosystem services and sources of livelihood for a vast majority (Lewis, 2006; FAO, 2011). While these features make tropical ecosystems unique and sought after, they are being lost at alarming rates, without a detailed understanding of their specific ecosystems. Studies on tropical ecosystems abound and have been able to give a general background on what exists in the tropics; however in depth studies concerning specific ecosystems (especially freshwater swamp forests) and its biodiversity patterns are lacking.

Even though the freshwater swamp forests are unique ecosystems which provide valuable ecosystem services such as the regulation of flood and maintenance of water quality by removing sediment and pollutants from moving water (Asthana \& Asthana, 2003), provision of timber and wood products, habitat for wildlife and recreation for bird-watching and fishing, their ecological relationships are poorly understood. Freshwater swamp forests are wetland ecosystems associated with low-lying areas along the lower reaches of rivers and around freshwater lakes. Being periodically inundated by river water, their soils are high in nutrients, often water logged and the trees grow rapidly, particularly where flooding results in physical disturbance of the forest (Thomas \& Baltzer, 2002). The ecosystem borders other forest ecosystems like lowland rainforest and mangrove swamp forests (James, 2008); given their restricted environmental range, they are prone to fragmentation and disturbance.

The Nigerian freshwater swamp forest is concentrated in the Niger delta where over 20 million people, including 40 ethnic groups, live (Spalding et al., 2010), and cover some $12,000 \mathrm{~km}^{2}$ or half of the delta (NDES, 1997). The main canopy of the forest is rather open and has almost impenetrable undergrowth (Keay, 1959). The ecosystem's initial inaccessibility prevented human incursions and subsequent depletion; however, with the myriad of activities ongoing in the Niger basin: crude oil exploration, infrastructural development, expansion of agriculture, timber harvesting, urbanization, population increase, dredging activities, land reclamation and flooding (Igu, 2017a), they are becoming degraded and threatened. Logging activities in the region have intensified since the development of roads and waterways opened up the region and made it accessible from market locations (Igu, 2016). Being the oil hub of the country (Ite et al., 2013), the region's population have grown over the years, and its associated impacts (like intensive agriculture to meet the growing population, urbanization, land reclamation and infrastructural development) have all culminated and contributed to an extensive and on-going depletion and degradation of the ecosystem.

Combined with this increasingly degraded state, most of the studies on the freshwater swamp forest ecosystem have been from the Neotropics, especially 
Brazil (Kurtz et al., 2013; Scarano et al., 1997), hence, forestalling the need to understand the freshwater swamp forest in other parts of the tropics. The lack of information about the ecosystem is more pronounced in Africa and Nigeria as a whole, with little or no information and understanding about the ecosystem since the initial rapid assessment on the composition and control of the ecosystem by Keay (1959). Documenting the biodiversity of this ecosystem through forest surveys and taxonomic inventories have become more necessary than ever, particularly in the Niger Delta (along the Niger basin) region of Nigeria where the ecosystem is the most extensive across Africa (Ogon, 2006) and covers up to half of the delta (NDES, 1997). This study is aimed at improving the baseline for the freshwater swamp forest across the region. To achieve this, the objectives are to: 1 ) document the existing composition of the ecosystem and show their varied abundance at the species and family levels, 2) show the variations in species richness, diversity and density of the ecosystem, 3) determine the variations that exist in the biodiversity indices within and across the sites and 4) compare the findings with other studies conducted elsewhere and show its priorities for conservation management. Part of the data on undisturbed freshwater swamp forest (for Otuwe forest) have been previously reported in Igu (2017b), but was used as it provided a basis for comparison with other results from the disturbed sites.

\section{Materials and Methods}

\subsection{Study Area}

The study was conducted in the Niger basin, being a part of the Niger delta that is a vast low lying sedimentary basin crisscrossed by a large number of meandering streams, rivers and creeks that drain the river Niger into the Atlantic Ocean at the Bight of Biafra (Figure 1). This part of the Niger Delta (between Latitude $4^{\circ}$ north of the Equator and Longitudes $5^{\circ}$ and $7^{\circ}$ east of the Greenwich) is drained by the river Niger and is where much of the remaining freshwater swamp forests are found (Figure 1). Areola (1982) broadly categorized the soils of this region as hydromorphic soils. They are described as seasonally or permanently waterlogged soils and are whitish or greyish in colour due to the reduction of oxides in the soils. The region has a tropical climate with long rainy season mainly from March/April to October. The flood regime begins in August, peaks in October and tapers off in December. The wet season lasts nearly throughout the year; the wet season peaks in July and the dry months are mainly between Decembers to February (Hughes \& Hughes, 1992). Relative humidity rarely dips below $60 \%$ and fluctuates between $90 \%$ and $100 \%$ for most of the year, with average monthly maximum and minimum temperatures varying between $28^{\circ} \mathrm{C}$ to $33^{\circ} \mathrm{C}$ and $21^{\circ} \mathrm{C}$ to $23^{\circ} \mathrm{C}$, respectively (James, 2008; NDES, 1997).

\subsection{Data Collection}

The sites were delimited after the vegetation map of Keay (1959). Selection of the sites was done to capture variations in disturbance among the sites using the 


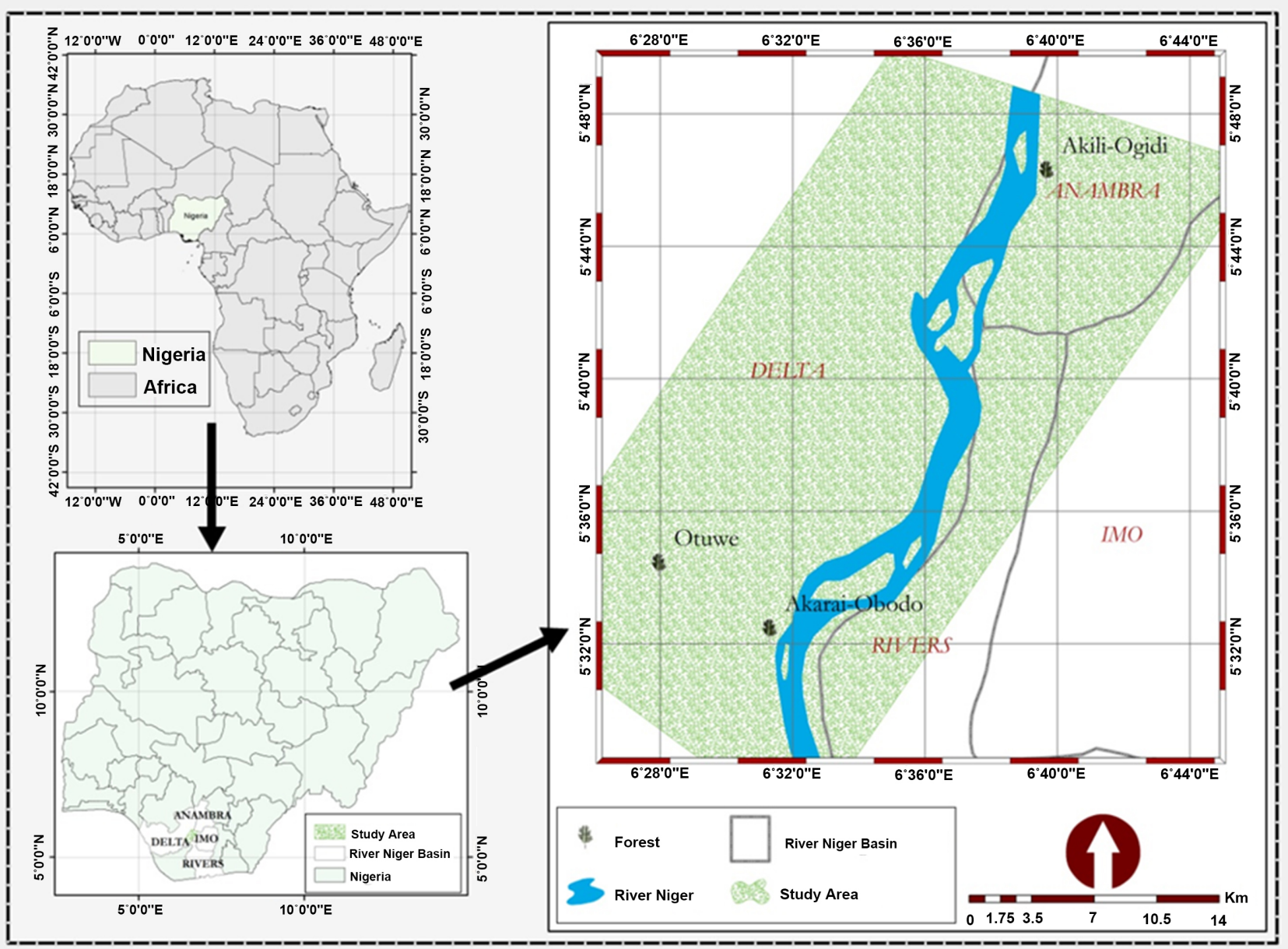

Figure 1. Map of the study area with the map of Nigeria and Africa inset.

presence of cut stems (stumps) and the sizes of stems. With the above guideline, three sites or locations that captured the issues were selected across the region (Figure 1). The first two sites: Akarai-Obodo (site 1) and Akili-Ogidi (site 2) are all secondary (disturbed) forests, while Otuwe (site 3) is an undisturbed forest.

Following Phillips et al. (2003), a standard plot-based method with a series of 1 ha square plots were established between December 2013 and April 2014. The plots were established along transects that were $1 \mathrm{~km}$ wide apart. This helped to ensure that there were variations in the floristic composition and consistency in enumeration of the plots. Each $100 \mathrm{~m} \times 100 \mathrm{~m}\left(1 \mathrm{ha}^{-1}\right)$ plot was further divided into blocks of $20 \times 20 \mathrm{~m}$ each in order to manage the enumeration. The stem sizes (diameter) of the trees were measured with a girth tape at their diameter breast height $(\mathrm{DBH}=130 \mathrm{~cm})$ or above the buttresses, where present. In each of the plots, only stems $\geq 10 \mathrm{~cm}$ were measured and identified, with the assistance of trained taxonomists from the Forestry Research Institute Ibadan (FRIN). Plant species were identified to species levels in the field, while voucher specimen were collected for unidentified ones and verified in FRIN herbarium afterwards. Plant identification followed the Taxonomy of Nigerian plants (Keay, 1989). The Akarai-Obodo and Akili-Ogidi site each contained 4 plots, while 8 
plots were set up at Otuwe. The variation in the number of plots per forest site was due to differences in the sizes of forest units.

\subsection{Data Analyses}

Importance values (IV) were used to characterize the forest sites and summarize the patterns and composition of the ecosystem across different forest locations. In addition to the frequency, density, basal area and dominance, relative values were used to ascertain the importance values for the species as well as that of the different families. The importance values were calculated after Cottam and Curtis (1956), Husch et al. (2003) and Mori et al. (1983) as follows:

$$
\begin{gathered}
\text { Relative Density }=100 \times \frac{\text { Number of stems of a species }}{\text { Total number of stems }} \\
\text { Relative frequency }=100 \times \frac{\text { Frequency of a species }}{\text { Sum of all species }} \\
\text { Relative dominance }=100 \times \frac{\text { Total basal area of a species }}{\text { Total basal area of all species }}
\end{gathered}
$$$$
\text { Basal Area }(B A)=\left(\frac{d b h}{2}\right)^{2} \times \pi
$$

Species importance values $(S I V)=$ Relative density + Relative frequency

+ Relative dominance

$$
\text { Relative diversity }=100 \times \frac{\text { Number of species in a family }}{\text { Total number of species }}
$$

Family importance values $(F I V)=$ Relative density + Relative dominance

$$
+ \text { Relative diversity }
$$

The importance values range from 0 to 300 indicating absence of dominance and monodominance respectively; dominant species or families were defined as those with values $\geq 10$ (Adomou et al., 2009).

The biodiversity indices of the ecosystem were calculated following Magurran (1998), Magurran (2004) and Kent and Coker (1992):

Shannon-Wiener index: (8)

$$
H^{\prime}=-\sum_{i=1}^{S} p i \ln p i
$$

where $H^{t}$ is the Shannon-Weiner index, $s$ is the total number of species, $p i$ is the proportion of individuals in the ith species, and $\ln$ is the natural logarithm.

Pielou's evenness index: (9)

$$
E=\frac{\sum_{i=1}^{S} p i \ln p i}{\ln (S)}
$$

Margalef s species richness index: (10)

$$
M=\frac{(S-1)}{\ln N}
$$




\section{Results}

The survey recorded a total of 116 species within 82 genera and 36 families across the 16 plots. As these hectares were from three different forest locations or sites, the results are thus presented according to the different forest sites below.

\subsection{Species Composition and Abundance across the Forest Sites}

\section{Akarai-Obodo (Site 1)}

This location recorded the highest number of plant species (80) compared to all other sites. While many species are found here, they are composed of three abundant species: Elaeis guineensis, Cleistopholis patens Engl. \& Diels and Sterculia oblonga with Importance values of 52, 29.4 and 28 respectively (Appendix 1). Malvaceae with the highest family importance value of 43.41 dominated the remaining 32 families that constitute the forest site. Other abundant families within the site includes: Rubiaceae, Arecacea and Leguminosae, in decreasing order (Appendix 2).

Akili-Ogidi (Site 2)

This forest location is made up of 58 plant species and 23 families. The species in the location are however dominated by Elaeis guineensis, Hexalobus crispiflorus A. Rich and Spondias mombin Jacq with 126.65, 13.91 and 10.74 species importance values respectively (Appendix 1). While most species' occurrence in the forest was less than 1\%, Elaeis guineensis had a $42.2 \%$ occurrence in the forest. The Arecaceae family had the highest family importance value of 111.7 in the forest, while other abundant families include: Malvaceae, Leguminosae and Annonaceae, in decreasing order (Appendix 2).

Otuwe (Site 3)

This forest location had the lowest number (35) of species and family (18) occurrence among other forest locations. Diospyros mespiliformis, Sterculia $o b-$ longa, Sterculia rhinopetala K. Schum and Celtis zenkeri Engl, with importance values of 83.61, 66.29, 35.51 and 26.32, respectively, were the dominant species in the site (Appendix 1). Malvaceae had the highest family importance value of 106.93, while the remaining three abundant families were Ebenaceae, Leguminosae and Cannabaceae with importance values of 72.36, 40.51 and 20.75, respectively (Appendix 2).

\subsection{Biodiversity Indices, Tree Abundance and Stem Sizes}

The species richness varied from the highest index of 8.65 in (Akarai-Obodo) to the least value of 0.52 in (Otuwe) (Table 1). The mean values of the different sites ranged from 6.74, 5.49, to 1.85 in Akarai-Obodo, Akili-Ogidi and Otuwe respectively. The evenness across the plots and sites varied from the highest index of 0.88 in site 1 , to its least value of 0.55 seen in site 3 (Table 1 ). Mean values across the forest sites ranged from $0.84,0.75$, to 0.72 in Akarai-Obodo, Akili-Ogidi and Otuwe respectively. The forest plots differed in their species 
Table 1. Biodiversity indices of the different sites.

\begin{tabular}{cccc}
\hline Site location & Diversity & Richness index & Evenness \\
\hline Akarai-Obodo (1) & 4.03 & 6.55 & 0.83 \\
Akarai-Obodo (1) & 4.04 & 6.36 & 0.86 \\
Akarai-Obodo (1) & 4.38 & 8.65 & 0.88 \\
Akarai-Obodo (1) & 3.56 & 5.4 & 0.78 \\
Akili-Ogidi (2) & 3.53 & 7.65 & 0.68 \\
Akili-Ogidi (2) & 3.64 & 5.88 & 0.77 \\
Akili-Ogidi (2) & 2.88 & 4.68 & 0.73 \\
Akili-Ogidi (2) & 3.31 & 3.74 & 0.81 \\
Otuwe (3) & 2.13 & 2.47 & 0.83 \\
Otuwe (3) & 1.78 & 1.43 & 0.81 \\
Otuwe (3) & 0.98 & 0.52 & 0.7 \\
Otuwe (3) & 1.88 & 3.26 & 0.64 \\
Otuwe (3) & 1.44 & 2.16 & 0.55 \\
Otuwe (3) & 1.47 & 1.34 & 0.71 \\
Otuwe (3) & 1.85 & 1.91 & 0.75 \\
Otuwe (3) & 1.76 & 1.71 & 0.77 \\
\hline
\end{tabular}

diversity across the sites. The highest Shannon diversity index of 3.38 was recorded in the first forest site (Akarai-Obodo), while the last site (Otuwe) had the least value of 0.98. Leguminosae and Malvaceae families had the highest number of species across the forest sites while others varied across the sites (Table 2). About $60 \%$ of the other families only had a single species in occurrence.

The number of tree stems varied across the plots and locations. The number of trees per plot $\geq 10 \mathrm{DBH}$ ranged from a least value of 94 to the highest value of 409. The pattern of stem density across the sites showed mean values of 193,138 and 255 tree stands $\cdot \mathrm{ha}^{-1}(\mathrm{dbh} \geq 10 \mathrm{~cm})$ in site 1,2 and 3 (Table 3). Khaya ivorensis $\mathrm{A}$. Chev had the highest stem size in site $1(112 \mathrm{~cm})$; Entandrophragma utile Sprague had the highest size of $185 \mathrm{~cm}$ in the second site and the highest overall size of $448 \mathrm{~cm}$ was accounted by Celtis zenkeri in site 3 . Stem density and diversity were varied across the sites due to the different disturbance state of each site.

\section{Discussion}

The species composition across the sites and plots differed in their patterns of dominance. The dominance of Malvaceae across the ecosystem was mainly from the genus Sterculia, which occurred in all the forest locations. The genus has distributional range in tropical areas of Africa and Asia and particularly in the West African countries of Nigeria, Benin, Cote d'Ivoire, Ghana, Guinea, Guinea-Bissau, Liberia, Mali, Togo and Sierra-Leone (Burkill, 1985; Keay, 1989; 
Table 2. Species rich families (with occurrence $\geq 4$ species).

\begin{tabular}{cccc}
\hline \multirow{2}{*}{ Family } & \multicolumn{3}{c}{ Number of species per forest site } \\
\cline { 2 - 4 } Site 1 & Site 2 & Site 3 \\
\hline Annonaceae & 4 & 5 & - \\
Apocynaceae & 6 & 4 & - \\
Leguminosae & 11 & 6 & 5 \\
Malvaceae & 7 & 10 & - \\
Meliaceae & 4 & 5 & - \\
Moraceae & 6 & 5 & - \\
Rubiaceae & 7 & - & \\
\hline
\end{tabular}

Table 3. Mean values of basal area, diversity and stem density across the forest locations.

\begin{tabular}{ccccc}
\hline Forest location & $\begin{array}{c}\text { Number of } \\
\text { plots (ha) }\end{array}$ & $\begin{array}{c}\text { Average basal area } \\
\left(\mathrm{m}^{2} \text { per ha }\right)\end{array}$ & $\begin{array}{c}\text { Average diversity } \\
\text { per ha }\end{array}$ & $\begin{array}{c}\text { Average stem density } \\
\text { per ha }\end{array}$ \\
\hline Akarai-obodo & 4 & $204,861.5 \pm 51,382.02$ & $4.00 \pm 0.34$ & $193.75 \pm 74.79$ \\
Akili-ogidi & 4 & $179,904.7 \pm 39,781.25$ & $3.34 \pm 0.34$ & $138 \pm 43.61$ \\
Otuwe & 8 & $421,830.5 \pm 164,251.2$ & $2.66 \pm 0.35$ & $255.13 \pm 88.16$ \\
\hline
\end{tabular}

Nussinovitch, 2010); and not restricted to the freshwater swamp forest ecosystem only. Though the dominance of Elaeis guineensis has been reported in other swamp forests (Keay, 1959; Ubom et al., 2012), it is however a reflection of the extent of the degradation, mainly from anthropogenic factors ongoing in the ecosystem. Being a secondary forest species which requires an open canopy to thrive, it dominates the freshwater swamp ecosystems that have undergone series of anthropogenic and natural disturbances. As such, it is a main flora of the first two sites which are more degraded than the third site where it only had a single stem/tree occurrence out of 2041 stems $\geq 10 \mathrm{DBH}$.

The Leguminosae family being another notable dominant family in the ecosystem recorded the highest number of species among all the families in the ecosystem. Being a major feature of the tropical (or Neotropical) rainforest ecosystem (Gentry, 1995, 1988; Duran et al., 2006; Romero-Duque et al., 2007; Fonty et al., 2011), it maintains its dominance through its multiple species presence. As such, the constraint associated with the ecosystem which limits the number of plant presence does not affect it in the same proportion with the other families with poorer species diversity. The genus Rhizophora was also found in plots associated with creeks and rivulets where disturbances have opened up spaces for them to thrive and where the degree of salinity (associated with the creeks) permits or is suitable for them to coexist with other freshwater swamp flora. It was not found in site 2 which even though was similar in terms of wetness but does not have the tiny creeks and inlets like other locations that permits the transportation of both their seeds and saline water for the facilitation of their propagation and coexistence. 
The freshwater swamp ecosystem is a floristically variable forest whose dominance is varied across different geographical scales. As such, the main feature that is found to dominate one location is not consistently the same across a landscape or region. In the Indo Malayan region for example, dominant species like: Melaleuca leucadendron, Ficus sp., Erythrina sp., Memecylon sp. have been reported (Wikramanayake et al., 2002); in the neotropics, dominant species like Tabebuia cassinoides, Tovomitopsis paniculata, Symphonia globulifera, Pterocarpus officinalis and families like: Clusiaceae, Bignoniaceae, Burseraceae, Arecaceae and Annonaceae were reported (Scarano et al., 1997; van Andel, 2003; Fickert \& Grüninger, 2010; Teixeira et al., 2011). This pattern is unlike other ecosystem like the lowland forests in the tropical and neotropical regions which are dominated by the Leguminosae family (Gentry, 1995, 1988; Duran et al., 2006) and the lowland (rainforest) forests of southwestern Nigeria which is dominated by Moraceae family (Adekunle et al., 2013). The freshwater swamp forests in the Niger basin are made up of floristic composition which occurs in other ecosystems, however its pattern of dominance and coexistence are varied and site specific.

Species diversity varied from site to site and from forest to forest, with some forest or sites being composed of large trees and diverse composition, while others have less (Table 3). The variation in the species diversity of the forest sites is mainly a function of disturbance. While the extent of disturbance, as well as land use and biogeochemical factors are undoubtedly responsible for the variations seen in forest landscapes, understanding how they apply to the local environment and specific ecosystems (such as the freshwater swamp) forest is very vital. This variation in the number of species found across the forest sites especially among the disturbed sites showed that the freshwater swamp forest ecosystem does not have uniform or consistent flora across large geographical scales, but are site specific and very variable. Even though the diversity of the forest sites increased with disturbance and the species richness improved with disturbance as well, such landscape's resilience reduces on the other hand since functional attributes such as invasion resistance tends to become more endangered (MacDougall et al., 2013).

The results of the patterns of stem abundance/density across the sites (Table 3) could be compared with the results from other tropical forests. Studies from tropical forests in Asia have shown tree densities of 349 - 627 stems $\cdot \mathrm{ha}^{-1}$ and 9 14 species in a dry tropical forest of Mirzapur district, Uttar Pradesh, India (Singh \& Singh, 1991); $217-292$ stems $\cdot \mathrm{ha}^{-1}$ in a dry tropical forest sanctuary in Raipur district, Chhattisgarh (Bijalwan, 2010); 428 stems.ha ${ }^{-1}$ in 95 species in a rainforest of Xishuangbana, China (Lu et al., 2010). African tropical forests have shown densities of 434 stems ( $\geq 10 \mathrm{~cm}$ dbh) in mixed tropical forest, and 340 stems in a monodominant forest in Cameroun (Lewis et al., 2013); 387 stems in 94 species in a strict nature reserve in southwest Nigeria (Adekunle et al., 2013). The stem densities are indeed similar and comparable with that of other tropical forests across the globe. These densities vary across the sites mainly due to the 
variations in disturbance regimes and capacities of each landscape to regrow after disturbance cycles. This on the other hand is responsible for the variations in basal area of the stems in each site.

Species richness of the ecosystem though varied, were generally low. This low species richness feature is however consistent with other freshwater swamp forests (Lugo et al., 1988; Scarano et al., 1997; Teixeira et al., 2011; Kurtz et al., 2013) due to environmental constraints associated with the ecosystem. The flooding regime that is associated with the ecosystem which inundates the soil exerts selective pressure on the composition and the structure of the ecosystem (Kurtz et al., 2013). Since the flood free environments required to facilitate reproduction and shallow water to prevent water-logging of seedlings or gas exchange (Lugo et al., 1998) are barely guaranteed for the ecosystem, it affects its richness and composition such that only those species with higher tendencies of adaptation could thrive in the ecosystem. Similar studies (Kurtz et al., 2013) reported lower species richness of the forests compared to the drier adjacent soil or forest locations.

As the ecosystem continues to undergo regimes of natural and anthropogenic disturbances, they provide gaps in the canopies of the forests and provide basis for regeneration and species diversity across the landscape. Such events go on to create opportunities for the addition of new species to the ecosystem and in turn facilitate the reinforcement and maintenance of the tree diversity in the ecosystem (Nakagawa et al., 2013).

\section{Conclusion}

The study documented an array of composition found across the ecosystem according to their respective abundance in the ecosystem. Their stem densities were similar with those of other tropical forest ecosystems, while their diversity increased with disturbance across the ecosystem. The ecosystem is characterized by general low species richness, as in other freshwater swamp forests in the Neotropics. This implies that the loss of any single species in the ecosystem poses a great threat to species' existence and conservation, and in turn, puts the ecosystem at the risk of ecosystem collapse. Furthermore, as the species diversity and rarity of the ecosystem are more associated with disturbed locations more than the intact zones, effective conservation of the ecosystem should be focused not only on the intact forest locations with higher basal area per hectare, but also on the disturbed locations whose higher species' value is vital for the stability of the ecosystem.

\section{Conflicts of Interest}

The authors declare no conflicts of interest regarding the publication of this paper.

\section{References}

Adekunle, V. A. J., Olagoke, A. O., \& Akindele, S. O. (2013). Tree Species Diversity and 
Structure of a Nigerian Strict Nature Reserve. Tropical Ecology, 54, 275-289.

Adomou, A. C., Akoegninou, A., Sinsin, B., De Foucault, B., \& Van Der Maesen, L. J. G. (2009). Semi-Deciduous Forest Remnants in Benin: Patterns and Floristic Characterization. Acta Botanica Gallica: Botany Letters, 156, 159-171. https://doi.org/10.1080/12538078.2009.10516148

Areola, O. (1982). Soils. In K. M. Barbour, J. S. Oguntoyinbo, J. O. C. Onyemelukwe, \& J. C. Nwafor (Eds.), Nigeria in Maps (pp. 22-23). London: Hodder and Stoughton.

Asthana, D. K., \& Asthana, M. (2003). Environmental Problems and Solutions. Ram Magar, New Delhi: Schannel and Company Ltd.

Bijalwan, A. (2010). Structure, Composition and Diversity of Degraded Dry Tropical Forest in Balamdi Watershed of Chhattisgarh Plain. Indian Journal of Biodiversity, 1, 119-124. https://doi.org/10.1080/09766901.2010.11884723

Bradshaw, C. J. A., Sodhi, N. S., \& Brook, B. W. (2009). Tropical Turmoil-A Biodiversity tragedy in Progress. Frontiers in Ecology and the Environment, 7, 79-87.

https://doi.org/10.1890/070193

Burkill, H. M. (1985). The Useful Plants of West Tropical Africa, Vol. 5. Kew: Royal Botanic Gardens.

Cottam, G., \& Curtis, J. T. (1956). The Use of Distance Measurements in Phytosociological Sampling. Ecology, 37, 451-460. https://doi.org/10.2307/1930167

Duran, E., Meave, J. A., Lott, E. J., \& Segura, G. (2006). Structure and Tree Diversity Patterns at the Landscape Level in a Mexican Tropical Deciduous Forest. Boletín de la Sociedad Botánica de México, 79, 43-60.

FAO (2011). The State of the World's Forest 2011. Rome: Food and Agriculture Organisation of the United Nations.

Fickert, T., \& Grüninger, F. (2010). Floristic Zonation, Vegetation Structure, and Plant Diversity Patterns within a Caribbean Mangrove and Swamp Forest on the Bay Island of Utila (Honduras). Ecotropica, 16, 73-92.

Fonty, E., Molino, J., Prevost, M., \& Sabatier, D, (2011). A New Case of Neotropical Monodominant Forest: Spirotropis longifolia (Legumiosae-Papilionoideae) in French Guiana. Journal of Tropical Ecology, 27, 641-644. https://doi.org/10.1017/S0266467411000356

Gardner, T. A., Barlow, J., Chazdon, R., Ewers, R. M., Harvey, C. A., Peres, C. A., \& Sodhi, N. S. (2009). Prospects for Tropical Forest Biodiversity in a Human-Modified World. Ecology Letters, 12, 561-582. https://doi.org/10.1111/j.1461-0248.2009.01294.x

Gentry, A. H. (1988). Changes in Plant Community Diversity and Floristic Composition on Environmental and Geographical Gradients. Annals of the Missouri Botanical Garden, 75, 1-34. https://doi.org/10.2307/2399464

Gentry, A. H. (1995). Diversity and Floristic Composition of Neotropical Dry Forest. In S. H. Bullock, H. A. Mooney, \& E. Medina (Eds.), Seasonally Dry Tropical Forests (pp. 146-194). Cambridge: Cambridge University Press. https://doi.org/10.1017/CBO9780511753398.007

Gibson, L. et al. (2011). Primary Forests Are Irreplaceable for Sustaining Tropical Biodiversity. Nature, 487, 378-381. https://doi.org/10.1038/nature10425

Hughes, R. H., \& Hughes, J. S. (1992). A Directory of African Wetlands. IUCN, UNEP, and WCMC, Gland, Nairobi and Cambridge.

Husch, B., Beers, T. W., \& Kershaw, J. A. (2003). Forest Mensuration (4th ed., 443 p.). New York: Wiley. 
Igu, N. I. (2016). Freshwater Swamp Forest Ecosystem in the Niger Delta: Ecology, Disturbance and Ecosystem Services. PhD Thesis, UK: University of York.

Igu, N. I. (2017a). Swamp Forest Use and Loss in the Niger Delta: Contextual and Underlying Issues. Open Journal of Forestry, 7, 34-47. https://doi.org/10.4236/ojf.2017.71003

Igu, N. I. (2017b). Species Diversity and Structure of an Intact Freshwater Swamp Forest in the Niger Delta. Open Journal of Forestry, 7, 242-254. https://doi.org/10.4236/ojf.2017.72015

Ite, A. E., Ibok, U. J., Ite, M. U., \& Petters, S. W. (2013). Petroleum Exploration and Production: Past and Present Environmental Issues in the Nigeria's Niger Delta. American Journal of Environmental Protection, 1, 78-90. https://doi.org/10.12691/env-1-4-2

James, G. K. (2008). Assessment of Environmental Change and Its Socio-Economic Impacts in the Mangrove Ecological Zone of the Niger Delta, Nigeria. PhD Thesis, Kansas City: University of Missouri-Kansas City.

Keay, R. W. (1959). An Outline of the Nigerian Vegetation. Lagos: Federal Department of Forest Research, Federal Ministry of Information.

Keay, R. W. J. (1989). Trees of Nigeria. Oxford: Clarendon Press.

Kent, M., \& Coker, P. (1992). Vegetation Description Analysis. Chichester: Wiley.

Kurtz, B. C., Gomes, J. C., \& Scarano, F. B. (2013). Structure and Phytogeographic Relationships of Swamp Forests of Southeast Brazil. Acta Botanica Brasilica, 27, 647-660. https://doi.org/10.1590/S0102-33062013000400002

Lewis, S. L. (2006). Tropical Forests and the Changing Earth System. Philosophical Transactions of the Royal Society of London B, 361, 195-210. https://doi.org/10.1098/rstb.2005.1711

Lewis, S. L., Sonké, B., Sunderland, T., Begne, S. K., López-González, G., van der Heijden, G. M. F., Phillips, O. L., Affum-Baffoe, K., Baker, T. R., Banin, L., Bastin, J., Beeckman, H., Boeckx, P., Bogaert, J., De Cannière, C., Chezeaux, E., Clark, C. J., Collins, M., Djagbletey, G., Djuikouo, M. N. K., Droissart, V., Doucet, J., Ewango, C. E. N., Fauset, S., Feldpausch, T. R., Foli, E. G., Gillet, J., Hamilton, A. C., Harris, D. J., Hart, T. B., de Haulleville, T., Hladik, A., Hufkens, K., Huygens, D., Jeanmart, P., Jeffery, K. J., Kearsley, E., Leal, M. E., Lloyd, J., Lovett, J. C., Makana, J., Malhi, Y., Marshall, A. R., Ojo, L., Peh, K. S., Pickavance, G., Poulsen, J. R., Reitsma, J., Sheil, D., Simo, M., Steppe, K., Taedoumg, H. E., Talbot, J., Taplin, J. R. D., Taylor, D., Thomas, S. C., Toirambe, B., Verbeeck, H., Vleminckx, J., White, L. J. T., Willcock, S., Woell, H., \& Zemagho, L. (2013). Aboveground Biomass and Structure of 260 African Tropical Forests. Philosophical Transactions of the Royal Society B, 368, Article ID: 20120295. https://doi.org/10.1098/rstb.2012.0295

Lu, X. T., Yin, J. X., \& Tang, J. W. (2010). Structure, Tree Species Diversity and Composition of Tropical Seasonal Rainforests in Xishuangbanna, South-West China. Journal of Tropical Forest Science, 22, 260-270.

Lugo, A. E., Brown, S., \& Brinson, M. M. (1998). Forested Wetlands in Freshwater and Salt-Water Environments. Limnology and Oceanography, 33, 894-909.

MacDougall, A. S., Mccann, K. S., Gellner, G., \& Turkington, R. (2013). Diversity Loss with Persistent Human Disturbance Increases Vulnerability to Ecosystem Collapse. Nature, 494, 86-89. https://doi.org/10.1038/nature11869

Magurran, A. E. (1998). Ecological Diversity and Its Measurement. Princeton, NJ: Princeton University Press.

Magurran, A. E. (2004). Measuring Biological Diversity. Oxford: Blackwell.

Mori, S. A., Boom, B. M., De Carvalino, A. M., \& Dos Santos, T. S. (1983). Southern Ba- 
hian Moist Forest. Botanical Review, 49, 155-232. https://doi.org/10.1007/BF02861011

Nakagawa, M., Momose, K., Kishimoto-Yamada, K. et al. (2013). Tree Community Structure, Dynamics, and Diversity Partitioning in a Bornean Tropical Forested Landscape. Biodiversity Conservation, 22, 127-140. https://doi.org/10.1007/s10531-012-0405-0

NDES (1997). The Niger Delta Environmental Survey. Environmental and Socio-Economic Characteristics. Lagos: Environmental Resources Managers Limited.

Nussinovitch, A. (2010). Plant Gum Exudates of the World: Sources, Distribution, Properties and Applications. Abingdon-on-Thames: Taylor and Francis.

Ogon, P. (2006). Land and Forest Resource Use in the Niger Delta: Issues in Regulation and Sustainable Management. Green Governance Project, Berkely, CA: Institute of International Studies.

Phillips, O. L., Nunez-Vargas, P., Monteagudo, A. L., Pena-Cruz, A., Chuspe-Zans, M. E., Galiano-Sánchez, W., Yli-Halla, M., \& Rose, S. (2003). Habitat Association among Amazonian Tree Species: A Landscape Scale Approach. Journal of Ecology, 91, 757-775. https://doi.org/10.1046/j.1365-2745.2003.00815.x

Pimm, S. L., \& Raven, P. R. (2000). Biodiversity: Extinction by Numbers. Nature, 403, 843-845. https://doi.org/10.1038/35002708

Romero-Duque, L. P., Jaramillo, V. J., \& Perez-Jimenez, A. (2007). Structure and Diversity of Secondary Tropical Dry Forests in Mexico, Differing in Their Prior Land-Use History. Forest Ecology and Management, 253, 38-47.

Scarano, F. R., Ribeiro, K. T., De Moraes, L. F. D., \& De Lima, H. C. (1997). Plant Establishment on Flooded and Unflooded Patches of a Freshwater Swamp Forest in Southeastern Brazil. Journal of Tropical Ecology, 14, 793-803.

https://doi.org/10.1017/S0266467400011007

Singh, L., \& Singh, J. S. (1991). Species Structure, Dry Matter Dynamics and Carbon Flux of a Dry Tropical Forest in India. Annals of Botany, 68, 263-273. https://doi.org/10.1093/oxfordjournals.aob.a088252

Spalding, M., Kainamu, M., \& Collins, L. (2010). World Atlas of Mangroves. Earthscan. https://doi.org/10.4324/9781849776608

Teixeira, A., Assis, M. A., \& Luize, B. G. (2011). Vegetation and Environmental Heterogeneity Relationships in a Neotropical Swamp Forest in Southeastern Brazil (Itirapina, SP). Aquatic Botany, 94, 17-23. https://doi.org/10.1016/j.aquabot.2010.10.001

Thomas, S. C., \& Baltzer, J. L. (2002). Tropical Forests. Encyclopedia of Life Sciences. Macmillan Publishers Ltd., Nature Publishing Group.

Ubom, R. M., Ogbemudia, F. O., \& Benson, K. O. (2012). Soil-Vegetation Relationship in Fresh Water Swamp Forest. Scientific Journal of Biological Sciences, 1, 43-51.

Van Andel, T. R. (2003). Floristic Composition and Diversity of Three Swamp Forests in Northwest Guyana. Plant Ecology, 167, 293-317. https://doi.org/10.1023/A:1023935326706

Wikramanayake, E., Dinerstein, E., Loucks, C. J. et al. (2002). Terrestrial Ecoregions of the Indo-Pacific: A Conservation Assessment. Washington DC: Island Press. 


\section{Appendix 1}

Table A1. Species importance values for all the forest sites.

\begin{tabular}{|c|c|c|c|}
\hline Species & Akarai-Obodo & Akili-Ogidi & Otuwe \\
\hline \multicolumn{4}{|l|}{ Abarema floribunda } \\
\hline Albizia ferruginea & 1.688261 & & \\
\hline Albizia spp & & & 1.182647 \\
\hline Alstonia boonei & 5.273127 & & 1.134639 \\
\hline Amphimas pterocarpoides & 1.666846 & & \\
\hline \multicolumn{4}{|l|}{ Aningeria robusta } \\
\hline \multicolumn{4}{|l|}{ Anogeissus leiocarpus } \\
\hline Anonidium mannii & & 2.154593 & \\
\hline Anthocleista djalonensis & 2.213826 & 1.262639 & 1.182452 \\
\hline Antiaris africana & 1.982069 & & \\
\hline \multicolumn{4}{|l|}{ Barteria fistulosa } \\
\hline Bombax buonopozense & 2.031561 & & \\
\hline Bosqueia angolensis & 4.167887 & & 1.182457 \\
\hline Brachystegia eurycoma & 2.246022 & & 3.904973 \\
\hline Brachystegia leonensis & 1.576329 & & \\
\hline Brachystegia nigerica & 1.862433 & 5.379226 & \\
\hline Canthium hispidum & 2.000241 & 2.151111 & \\
\hline Ceiba pentandra & 5.940044 & 6.490513 & \\
\hline Celtis zenkeri & 1.923731 & & 26.32844 \\
\hline Chrysophyllum albidum & 1.898732 & 1.075445 & \\
\hline Chrysophyllum perpulchrum & & 1.078215 & \\
\hline \multicolumn{4}{|l|}{ Chytranthus spp } \\
\hline Cleistopholis patens & 29.45342 & 4.660224 & 4.124914 \\
\hline \multicolumn{4}{|l|}{ Coelocaryon preussii } \\
\hline Cola acuminata & & 1.075155 & \\
\hline Cola gigantea & 2.488194 & 2.347414 & \\
\hline Cola glabra & & 1.839652 & \\
\hline Cola laurifolia & 0.825137 & 5.574301 & \\
\hline Cola millenii & & 1.258239 & \\
\hline \multicolumn{4}{|l|}{ Cordia millenii } \\
\hline \multicolumn{4}{|l|}{ Dacryodes edulis } \\
\hline Desplatsia dewevrei & 3.51052 & & \\
\hline Dialium guineensis & 1.090339 & 2.344116 & \\
\hline Dichapetalum madagascariense & 0.962355 & & \\
\hline Digitaria debilis & 0.962717 & & \\
\hline
\end{tabular}




\section{Continued}

\begin{tabular}{|c|c|c|c|}
\hline Diospyros dendo & 0.968501 & & \\
\hline Diospyros crassiflora & & & 4.506656 \\
\hline Diospyros mespiliformis & 5.338611 & 1.074898 & 83.61359 \\
\hline \multicolumn{4}{|l|}{ Diospyros nigerica } \\
\hline Discoglypremna caloneura & 3.609703 & & \\
\hline \multicolumn{4}{|l|}{ Dryopteris floridana } \\
\hline Elaeis guineensis & 52.00559 & 126.6598 & 1.134632 \\
\hline Enantia chlorantha & 1.273874 & & \\
\hline Entandrophragm candollei & & 1.080146 & \\
\hline Entandrophragm utile & & 2.247097 & \\
\hline Entandrophragma angolense & 0.825435 & & \\
\hline Eribroma oblonga & 2.182032 & & \\
\hline \multicolumn{4}{|l|}{ Erythrina spp } \\
\hline Erythrophleum ivorense & 2.06397 & & 13.31255 \\
\hline Erythrophleum spp & & & 1.903386 \\
\hline Ficus capensis & 0.825137 & 5.302325 & \\
\hline Ficus exasperata & & & 2.317183 \\
\hline Ficus mucuso & 8.633911 & 1.271621 & 3.404889 \\
\hline Funtumia elastica & 0.827792 & 5.028155 & \\
\hline Garcinia kola & & 1.629011 & \\
\hline Guarea cedrata & 1.812063 & 1.075882 & \\
\hline Hallea ciliata & 9.629677 & & \\
\hline Hallea stipulosa & 0.828533 & & \\
\hline Hexalobu crispiflorus & & 13.91045 & \\
\hline Holarrhena floribunda & 0.962355 & 1.444515 & \\
\hline Hunteria umbellata & 0.837557 & & 1.134745 \\
\hline Hylodendron gabunense & 0.962355 & 9.223245 & \\
\hline Irvingia gabonensis & 0.827444 & 6.319821 & \\
\hline Isoberlina doka & & 5.364762 & \\
\hline Khaya grandifoliola & 1.172013 & & 1.134665 \\
\hline Khaya ivornensis & 4.094591 & & \\
\hline Lagerstroemia speciosa & & 5.930298 & \\
\hline Lannea schweinfurthii & & 1.082442 & \\
\hline \multicolumn{4}{|l|}{ Lannea welwitschii } \\
\hline Lecaniodiscus cupanioides & 1.662038 & 2.342669 & 2.317108 \\
\hline Lophira alata & 9.547587 & & \\
\hline Lophira lanceolata & & & \\
\hline
\end{tabular}




\section{Continued}

\begin{tabular}{|c|c|c|c|}
\hline Macaranga barteri & 2.196274 & & \\
\hline \multicolumn{4}{|l|}{ Maesopsis eminii } \\
\hline Malacantha alnifolia & 0.970397 & 2.158558 & \\
\hline Mangifera indica & & 2.771867 & \\
\hline \multicolumn{4}{|l|}{ Manilkara obovata } \\
\hline Margaritaria discoidea & 0.825137 & 1.278033 & \\
\hline Melaleuca leucadendra & 0.833518 & & \\
\hline Memecylon afzelii & 0.825282 & 1.076123 & \\
\hline \multicolumn{4}{|l|}{ Memecylon spp } \\
\hline Milicia excelsa & & 3.515729 & \\
\hline Milicia regia & & 1.075345 & \\
\hline Millettia thonningii & & 2.338638 & 1.134632 \\
\hline Mitragyna inermis & 0.831446 & & \\
\hline Mitragyna stipulosa & 4.380536 & & \\
\hline Monodora myristica & 1.815984 & 1.474119 & \\
\hline Morinda lucida & & 3.438922 & \\
\hline Morus mesozyia & 0.824802 & & \\
\hline Musanga cecropioides & 1.857842 & & \\
\hline Myrianthus arboreus & 2.23528 & & \\
\hline Napoleonaea vogelii & 2.94418 & & 1.278873 \\
\hline Nauclea diderrichii & & 1.078215 & \\
\hline Nauclea stipulosa & 2.884921 & & 6.566734 \\
\hline Vesogordonia papaverifera & & & 1.328563 \\
\hline \multicolumn{4}{|l|}{ Octolobus angustatus } \\
\hline Parinari robusta & 2.266607 & & 2.221846 \\
\hline Patabea capitellata & 1.655753 & & \\
\hline Pentaclethra macrophylla & 0.827133 & & \\
\hline \multicolumn{4}{|l|}{ Pentadesma butyracea } \\
\hline Picralima nitida & 0.963652 & 2.539741 & \\
\hline iptadeniastrum africanum & 2.210919 & & \\
\hline Pterocarpus santalinoides & 3.455573 & 1.258704 & 6.437034 \\
\hline Pterocarpus soyauxii & & & 5.331148 \\
\hline Pterocarpus spp & & & 4.237953 \\
\hline Pterygota macrocarpa & & 1.776064 & \\
\hline Pycnanthus angolensis & 2.866712 & & 1.23056 \\
\hline \multicolumn{4}{|l|}{ Raphia spp } \\
\hline Raphia sudanica & 2.930847 & & \\
\hline
\end{tabular}




\section{Continued}

\begin{tabular}{|c|c|c|c|}
\hline Rauvolfia spp & 1.649942 & & \\
\hline Rauvolfia vomitoria & & 1.074745 & \\
\hline Rhizophora mangle & 0.831446 & & \\
\hline Rhizophora racemosa & 7.91984 & & 2.317417 \\
\hline \multicolumn{4}{|l|}{ Rhizophora spp } \\
\hline Ricinodendron heudelotii & 0.834263 & 1.298952 & \\
\hline Rinorea dentata & 1.647195 & & \\
\hline \multicolumn{4}{|l|}{ Rothmannia spp } \\
\hline Spathodea campanulata & 1.794041 & 3.254281 & \\
\hline Spondias mombin & 6.178376 & 10.74476 & \\
\hline \multicolumn{4}{|l|}{ Staudtia stipitata } \\
\hline Sterculia africana & & 1.139104 & \\
\hline Sterculia oblonga & 28.07248 & & 66.29354 \\
\hline Sterculia rhinopetala & 4.12768 & 1.077231 & 35.51309 \\
\hline Sterculia tragacantha & & 2.933026 & 1.376623 \\
\hline Strombosia grandifolia & & & 3.120082 \\
\hline Strombosia pustulata & 5.322241 & 1.633595 & 4.291599 \\
\hline Terminalia avicennioides & 2.516946 & & \\
\hline Terminalia glaucescens & 1.139711 & & \\
\hline Terminalia $s p p$ & & & 1.134634 \\
\hline Terminalia superba & 1.42714 & & \\
\hline Tetrapleura tetraptera & & & 1.134715 \\
\hline Treculia africana & 6.577993 & 8.526626 & \\
\hline Trichilia monadelpha & & 6.247534 & \\
\hline Uapaca guineensis & & 1.075345 & \\
\hline Uapaca togoensis & 0.977829 & & \\
\hline Vitex doniana & & 3.387174 & \\
\hline Xylopia aethiopica & 1.725525 & 1.074859 & 1.231034 \\
\hline Zanthoxylum zanthoxyloides & & 1.074745 & \\
\hline
\end{tabular}




\section{Appendix 2}

Table A2. Family importance values of the forest sites.

\begin{tabular}{|c|c|c|c|}
\hline Family & Akarai-Obodo & Akili-Ogidi & Otuwe \\
\hline Anacardiaceae & 2.326875392 & 10.7531479 & - \\
\hline Annonaceae & 21.54616439 & 24.0358095 & 6.327382 \\
\hline Apocynaceae & 13.68306688 & 10.9453741 & 5.500882 \\
\hline Arecaceae & 31.43476464 & 111.73514 & 2.750374 \\
\hline Bignoniaceae & 1.647105548 & 2.29498454 & - \\
\hline Boraginaceae & - & - & - \\
\hline Burseraceae & - & - & - \\
\hline Cannabaceae & 11.46649296 & - & 20.75239 \\
\hline Chrysobalanaceae & 2.943130047 & - & 2.750537 \\
\hline Clusiaceae & - & 2.45855428 & - \\
\hline Combretaceae & 6.697683047 & - & 2.750375 \\
\hline Dichapetalaceae & 1.513550285 & - & - \\
\hline Dryopteridaceae & - & - & - \\
\hline Ebenaceae & 3.560009764 & 1.90604619 & 72.36145 \\
\hline Euphorbiaceae & 20.90501934 & 2.12362815 & - \\
\hline Gentianaceae & 1.793739678 & 2.09279409 & 2.798137 \\
\hline Irvingiaceae & 1.381257431 & 4.38585439 & - \\
\hline Lamiaceae & - & 3.30263665 & - \\
\hline Lecythidaceae & 2.485428041 & - & 2.894153 \\
\hline Leguminosae & 28.45146696 & 24.91781 & 40.5147 \\
\hline Lythraceae & - & 6.54819949 & - \\
\hline Malvaceae & 43.41755092 & 31.5052189 & 106.9306 \\
\hline Melastomataceae & 1.380086734 & 1.90708591 & - \\
\hline Meliaceae & 8.583727185 & 16.0890486 & 2.750395 \\
\hline Moraceae & 22.47994868 & 19.8750625 & 8.491825 \\
\hline Myristicaceae & 1.582812675 & - & 5.548783 \\
\hline Myrtaceae & 1.384547581 & - & - \\
\hline Ochnaceae & 3.758184234 & - & - \\
\hline Olacaceae & 2.486928279 & 2.46244664 & 7.400022 \\
\hline Passifloraceae & - & - & - \\
\hline Phyllanthaceae & 4.846542261 & 4.0216475 & - \\
\hline Poaceae & 2.934935178 & - & - \\
\hline Rhamnaceae & - & - & - \\
\hline Rhizophoraceae & 3.985304624 & - & 2.846018 \\
\hline Rubiaceae & 34.70823489 & 6.52173711 & 3.786145 \\
\hline Rutaceae & - & 1.90591623 & - \\
\hline Sapindaceae & 4.100367167 & 2.27905925 & 2.845823 \\
\hline Sapotaceae & 3.91789855 & 5.93279789 & - \\
\hline Sterculiaceae & 1.942724369 & - & - \\
\hline Urticaceae & 5.119861064 & - & - \\
\hline Violaceae & 1.534591196 & - & - \\
\hline
\end{tabular}

